\title{
Production of Xylo-oligosaccharides (XOS) by controlled hydrolysis of Xylan using immobilized Xylanase from Aspergillus niger with improved properties
}

\author{
Caio C Aragon ${ }^{1,2}$, Ana I Ruiz-Matute ${ }^{3,4}$, Nieves Corzo ${ }^{4}$, Rubens Monti ${ }^{5}$, Jose M Guisán $^{1 *}$ and Cesar Mateo ${ }^{1 *}$ \\ ${ }^{1}$ Instituto de Catálisis y Petroleoquímica, CSIC, Marie Curie 2, 28049, Cantoblanco, Madrid, Spain \\ ${ }^{2}$ Institute of Chemistry, Department of Biochemistry and Chemical Technology, UNESP - Univ. Estadual Paulista, Araraquara, SP, Brazil \\ ${ }^{3}$ Instituto de Investigación en Ciencias de la Alimentación (CIAL), CSIC, \\ 28049 Madrid, Spain \\ ${ }^{4}$ Instituto de Química Orgánica General (IQOG), CSIC, Juan de la Cierva 3, 28006 Madrid, Spain \\ ${ }^{5}$ Faculty of Pharmaceutical Sciences, Department of Food and Nutrition, UNESP - Univ. Estadual Paulista, Araraquara, SP, Brazil
}

\begin{abstract}
The production of xylo-oligosaccharides from xylan using an optimal immobilized catalyst of xylanase from Aspergillus niger is presented. The enzyme extract has several xylanases with different properties doing necessary the development of cheap and simple methods to purify them at industrial scale. The enzyme was successfully purified, immobilized and highly stabilized using a simple protocol. The principal purified xylanase was a $34 \mathrm{KDa}$ protein corresponding with $50 \%$ of the endo-xylanase activity of the total strain. Among the different immobilization assayed protocols, the use of aldehyde support allowed the complete immobilization of this fraction keeping $80 \%$ of its initial catalytic activity. An optimization of this method promoted a stabilization factor of around 1100 -fold more stable than soluble enzyme. The use of the optimal catalyst allowed a maximum hydrolysis degree of $73.4 \%$. The optimization of the reaction conditions (different time and temperature) allowed producing $62 \%(11.93 \mathrm{mg} / \mathrm{mL})$ of interesting xylooligo-saccharides (XOS2-XOS6) (Figure 1).
\end{abstract}
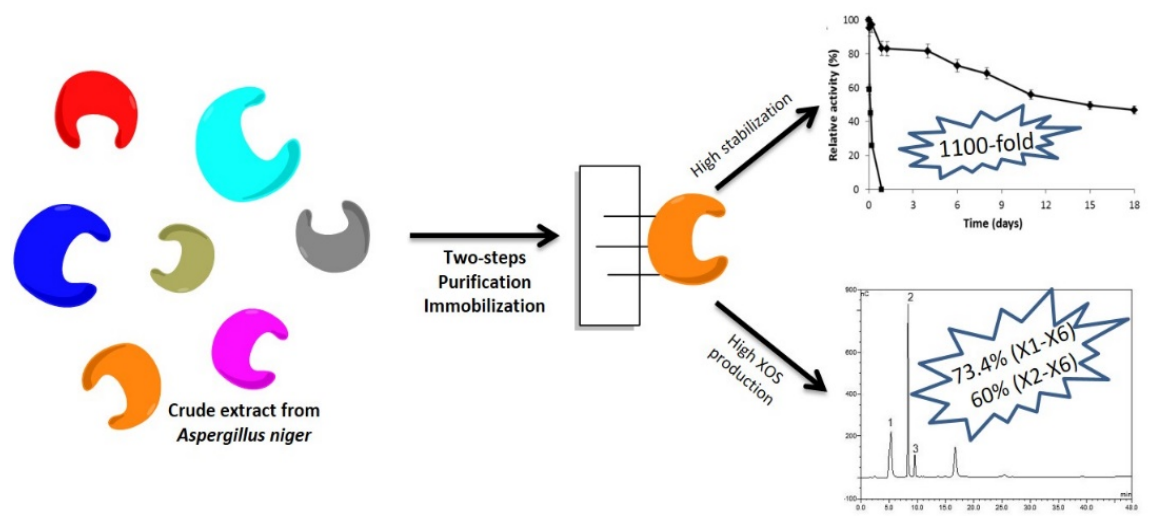

Figure 1. Graphical abstract

\section{Introduction}

The xylan represents the most abundant natural polysaccharide in nature after cellulose. The xylan consists of a linear polymer of $\beta-(1-$ 4)-D-xylopyranosyl units which can be substituted with 4-O-methyl- $\alpha$ $D$-glucuronopyranosyl units, acetyl groups or $\alpha$ - $L$-arabinofuranosyl in variable proportions [1].

Xylan is mainly hydrolyzed by endo-xylanases to produce xylooligosaccharides (XOS) mixtures, which are considered as emerging prebiotics. Among the health benefits attributed to XOS, the increase of bifidobacteria and Lactobacillus, the decrease of pathogenic and

${ }^{*}$ Correspondence to: Cesar Mateo, Instituto de Catálisis y Petroleoquímica, CSIC, Marie Curie 2, 28049, Cantoblanco, Madrid, Spain, Tel: 34915854768; Fax: 34915854760; E-mail: ce.mateo@icp.csic.es

José Manuel Guisán, Instituto de Catálisis y Petroleoquímica, CSIC, Marie Curie 2, 28049, Cantoblanco, Madrid, Spain, Tel: 34915854809; Fax: 34915854760; E-mail: jmguisan@icp.csic.es

Key words: Xylanase, Aspergillus niger, biocatalysis, enzyme thermostabilization, XOS production

Received: July 07, 2018; Accepted: July 27, 2018; Published: July 31, 2018 

properties

putrefactive bacteria, the improvements in bowel function and calcium absorption, the immunological properties, and antioxidant, antiinflammatory or antiallergic activities are included [2]. The conversion of the oligosaccharides into xylose can be catalyzed by $\beta$-xylosidases. Xylose can be used such as carbon source in ethanol production or can be chemically or enzymatically transformed into other products such as xylitol, which is an important non-caloric sweetener, using a xylose reductase [3].

There are reported endo-xylanases from different sources such as fungi or bacteria and usually can be inducted when microorganisms are grown using xylan as carbon source. An industrially attractive alternative is the use of abundantly available and cost-effective agricultural residues (wheat bran, corn cobs, corn stover, rice bran, rice husk, etc.) to obtain the enzyme with reduction of the overall manufacturing cost [4].

The crude strains obtained after culture of different carbon sources are usually composed of different endo-, exo-xylanases and other enzymes that can catalyze the transformation of the desired products into other different compounds; even the use of a mixture of endoxylanases difficult the control of the process because the properties of the global catalyst (activity, stability and selectivity) are a mixture of those of all the enzymes.

On the other hand, Aspergillus niger is able to produce up to 15 different xylanases depending on the fermentation conditions [5]. This makes necessary the design of easy purification processes. Considering that the use of soluble enzyme at industrial level is in many cases expensive, it is usually convenient the use of the enzyme as immobilized preparation in order to reuse the catalyst improving the productivity and permitting an easier design of the reactors, avoiding expensive purification processes. Due the importance of immobilizing the enzyme, it is also highly interesting using the immobilization processes to produce more stable biocatalysts. This may permit catalyzing the hydrolysis of agricultural wastes into prebiotics with added value minimizing the cost of the process.

Especially in the last decade, xylanases from different sources have been immobilized using different protocols allowing different improvements on their operational properties (Table 1) [6-32].

Therefore, in this work, a simple protocol for the purification, immobilization and stabilization of two different xylanases from $A$. niger is presented. The optimal catalyst was used to study and optimize the reaction of hydrolysis of xylan into different oligosaccharides with industrial interest.

\section{Materials and methods}

\section{Materials}

Endo-1,4- $\beta$-xylanase was produced by A. niger. Agarose 10 BCL was purchased from Agarose Bead Technologies (Madrid, Spain). Epichlorhydrine, iminodiacetic acid, $p$-aminophenyl boronic acid, triethylamine, ethanolamine, polyethyleneimine, beechwood xylan, xylose, glycidol, sodium borohydride, sodium periodate and 3-5'-dinitrosalicylic acid were obtained from Sigma-Aldrich Co (St. Louis, United States). Powdered corncob was kindly donated by Rasul (Andirá, Brazil). Carboxymethyl-sepharose fast flow, Q-sepharose fast flow, CNBr-activated 4B sepharose and SDS-PAGE low molecular weight standards were purchased from GE Healthcare Life Sciences (Uppsala, Sweden), and the xylo-oligosaccharides standards (X2-X6) from Megazyme (Bray, Ireland). All reagents were of analytical grade.

\section{Methods}

\section{Endo-1,4- $\beta$-xylanase production}

Aspergillus niger was used for xylanase production. Cultures were grown on $2 \%(\mathrm{w} / \mathrm{v})$ agar and $4 \%(\mathrm{w} / \mathrm{v})$ oat flour at $40^{\circ} \mathrm{C}$ for four days. Enzyme production was performed as described by Benedetti et al. [33], with powdered corncobs as carbon source. The crude extract was filtered through filter paper under vacuum and lyophilized.

\section{Enzyme assay and protein determination}

Reducing sugar released after enzymatic hydrolysis of xylan was colorimetrically determined by reaction with 3-5'-dinitrosalicylic acid (DNS), according the described method [34]. Xylose was used as standard reducing sugar for calibrations.

Soluble substrate was prepared mixing $40 \mathrm{mg} / \mathrm{mL}$ of beechwood xylan in $100 \mathrm{mM}$ sodium acetate at $\mathrm{pH}$ 5. The mixture was stirred for 30 minutes at $25^{\circ} \mathrm{C}$ and centrifuged for 20 minutes at $5,000 \mathrm{~g}$. The soluble fraction was separated and used as substrate for the reaction. Thus, the final substrate concentration used in this study was $20 \mathrm{mg} / \mathrm{mL}$. The assay was performed at $25^{\circ} \mathrm{C}$ with mild stirring. This temperature was chosen against the optimal (around $55^{\circ} \mathrm{C}$ ) to facilitate the measures in standard conditions and eliminating the possibility of inactivation at higher temperatures by long time reactions. One enzyme unit (U) was defined as the amount of enzyme capable of producing $1 \mu \mathrm{mol}$ of reducing sugar per minute in these conditions.

Protein was determined with the Bradford's method [35] using bovine serum albumin (fraction $\mathrm{V}$ ) as the protein standard.

\section{Preparation of immobilization supports}

Glyoxyl supports were obtained after activation of agarose 10 BCL with aldehyde groups as previously described by Guisan [36]. Polyethylenimine-agarose (PEI-agarose) support was prepared according to Mateo et al. [37] using glyoxyl agarose supports as starting material. Iminodiacetic acid-agarose (IDA-agarose), boronate-agarose and amino-agarose supports were prepared as described by Mateo et al. [38] using epoxy-activated agarose as base support. $\mathrm{Cu}^{2+}$-chelateagarose was prepared by incubating the support previously activated with iminodiacetic acid in a $20 \mathrm{mM}$ solution of $\mathrm{CuSO}_{4}$ for 30 minutes and then washed with distilled water [39].

\section{Enzyme purification and immobilization}

The different preparations were all performed with a low enzymatic load in order to avoid possible mass limitation transfers.

Purification: The preparation of the enzyme using the crude strain as starting material was performed depending on the support used. Thus, $2 \mathrm{mg}$ of xylanase (measured by the Bradford method) containing $2 \mathrm{U} / \mathrm{mg}$ was solubilized in sodium phosphate buffer at pH 7 (5 mM phosphate for immobilizing on ion-exchange supports; $50 \mathrm{mM}$ phosphate for immobilization on boronate support and 100 $\mathrm{mM}$ for use with $\mathrm{Cu}^{2+}$-chelate agarose). Then, the immobilization on different supports was performed by adding $1 \mathrm{~g}$ of support in $10 \mathrm{~mL}$ of the enzyme solution at $25^{\circ} \mathrm{C}$. The enzyme adsorbed on the $\mathrm{Cu}^{2+}$-chelate agarose was desorbed with $20 \mathrm{mM}$ imidazol.

Immobilization: $2 \mathrm{mg}$ of pure xylanase (containing $16.8 \mathrm{U} /$ $\mathrm{mg}$ ) was diluted in $10 \mathrm{~mL}$ of the buffer solution $(100 \mathrm{mM}$ sodium bicarbonate $\mathrm{pH} 10$ or $100 \mathrm{mM}$ sodium phosphate $\mathrm{pH}$ 7) and offered to $1 \mathrm{~g}$ of glyoxyl agarose or $\mathrm{CNBr}$-activated Sepharose supports. When the immobilization was completed the glyoxyl derivative was reduced by adding $1 \mathrm{mg} / \mathrm{mL}$ of solid $\mathrm{NaBH}_{4}$ for 30 minutes and then washed 
Aragon CC (2018) Production of Xylo-oligosaccharides (XOS) by controlled hydrolysis of Xylan using immobilized Xylanase from Aspergillus niger with improved properties

Table 1. Immobilization of endo-xylanases reported in the literature

\begin{tabular}{|c|c|c|c|c|c|c|c|}
\hline Xylanase source & Support / activation & $\begin{array}{l}\text { Molecular } \\
\text { mass (kDa) }\end{array}$ & $\begin{array}{l}\text { Type of } \\
\text { immobilization }\end{array}$ & $\begin{array}{l}\text { Recovered activity } \\
(\%)\end{array}$ & $\begin{array}{l}\text { Immobilization yield } \\
(\%)\end{array}$ & Stability factor & References \\
\hline Armillaria gemina & Silicon oxide nanoparticles & 47 & Covalent & 117 & 69.2 & $4.5\left(50^{\circ} \mathrm{C}\right)$ & {$[6]$} \\
\hline Aspergillus niger & Eudragit L-100 & 24 & Adsorption & 60 & 93 & nd & [7] \\
\hline Aspergillus niger & $\begin{array}{l}\text { Chitosan treated with dialdehyde } \\
\text { starch }\end{array}$ & nd & Covalent & 60.8 & 71.2 & $3\left(55^{\circ} \mathrm{C}\right)$ & {$[8]$} \\
\hline Aspergillus niger & $\begin{array}{l}\text { Alginate beads treated with } \\
\text { glutaraldehyde }\end{array}$ & 32 & Covalent & nd & 94.6 & $1.5\left(55^{\circ} \mathrm{C}\right)$ & [9] \\
\hline $\begin{array}{l}\text { Aspergillus niveus expressed in } \\
\text { Aspergillus nidulans }\end{array}$ & Glyoxyl-agarose & 36 & Covalent & 83 & 100 & $8.5\left(70^{\circ} \mathrm{C}\right)$ & {$[10]$} \\
\hline Aspergillus sp. (strain 44) & Eudragit S-100 & nd & Adsorption & 80 & 100 & $2.5\left(60^{\circ} \mathrm{C}\right)$ & {$[11]$} \\
\hline Aspergillus sp. (strain 5) & Eudragit S-100 & nd & Adsorption & 70 & 99 & $2\left(60^{\circ} \mathrm{C}\right)$ & {$[11]$} \\
\hline Aspergillus tamarii & $\begin{array}{l}\text { Duolite A147 treated with } \\
\text { glutaraldehyde }\end{array}$ & nd & Covalent & 54.2 & 48.4 & $1.3\left(60^{\circ} \mathrm{C}\right)$ & {$[12]$} \\
\hline Aspergillus terreus F-413 & $\begin{array}{l}\text { Porous glass beads treated with } \\
\text { 3-aminopropyltriethoxysilane }\end{array}$ & nd & Covalent & nd & 100 & nd & {$[13]$} \\
\hline Aspergillus versicolor & Glyoxyl-agarose & 21 & Covalent & 84 & 88 & $700\left(60^{\circ} \mathrm{C}\right)$ & {$[14]$} \\
\hline Bacillus halodurans & Lewatit MonoPlus MP64 & 45 & Adsorption & nd & 60.2 & nd & {$[15]$} \\
\hline Bacillus pumilus MK001 & Q-Sepharose & nd & Adsorption & 45 & 15.8 & nd & {$[16]$} \\
\hline Bacillus pumilus MK001 & HP-20 beads & nd & Covalent & 42 & 18 & nd & {$[16]$} \\
\hline $\begin{array}{l}\text { Bacillus pumilus SV-205 MTCC } \\
9862\end{array}$ & $\begin{array}{l}\text { Aluminum oxide treated with } \\
\text { glurataldehyde }\end{array}$ & nd & Covalent & 83.6 & nd & $1.2\left(70^{\circ} \mathrm{C}\right)$ & {$[17]$} \\
\hline NS50014 (Novozymes) & Epoxy-chitosan & nd & Covalent & 64 & 100 & $1.3\left(75^{\circ} \mathrm{C}\right)$ & [18] \\
\hline NS50014 (Novozymes) & $\begin{array}{l}\text { Glyoxyl-agarose (after enzyme } \\
\text { amination) }\end{array}$ & nd & Covalent & nd & 100 & $40\left(70^{\circ} \mathrm{C}\right)$ & {$[18]$} \\
\hline Pholiota adiposa & Silicon oxide nanoparticles & 37 & Covalent & 144 & 66 & nd & [19] \\
\hline Pulpzyme HC (Novozymes) & Cellulose acetate membranes & nd & Covalent & nd & nd & nd & {$[20]$} \\
\hline Streptomyces halstedii & Glyoxyl-agarose & 32.6 & Covalent & 65 & 95 & $200\left(60^{\circ} \mathrm{C}\right)$ & [21] \\
\hline $\begin{array}{l}\text { Streptomyces olivaceoviridis } \\
\text { E-86 }\end{array}$ & Eudragit S-100 & 47 & Adsorption & 92 & 99.5 & $1.6\left(60^{\circ} \mathrm{C}\right)$ & {$[22]$} \\
\hline Talaromyces thermophilus & $\begin{array}{l}\text { Gelatin treated with } \\
\text { glutaraldehyde }\end{array}$ & nd & Covalent & 100 & 98.8 & $1.5\left(100^{\circ} \mathrm{C}\right)$ & {$[23]$} \\
\hline Thermomyces lanuginosus & Nanoporous gold & 25 & Covalent & nd & nd & nd & {$[24]$} \\
\hline Thermomyces lanuginosus SSBP & Eudragit S-100 & 24 & Adsorption & 75 & 100 & nd & {$[25]$} \\
\hline Thermotoga maritima $(\mathrm{XynB})$ & Nickel-chelate Eupergit C 250L & 40 & $\begin{array}{l}\text { Adsorption / } \\
\text { Covalent }\end{array}$ & 76.3 & 98.7 & nd & {$[26]$} \\
\hline $\begin{array}{l}\text { Thermotoga sp. (strain } \\
\text { FjSS3-B.1) }\end{array}$ & Porous glass beads & 31 & Covalent & nd & 85 & $5\left(105^{\circ} \mathrm{C}\right)$ & {$[27]$} \\
\hline Trichoderma reesei & Polysulfone acrylate membranes & nd & Covalent & nd & nd & nd & {$[28]$} \\
\hline Trichoderma reesei & Eudragit L-100 & nd & $\begin{array}{l}\text { Adsorption / } \\
\text { Covalent }\end{array}$ & 59 & 69 & nd & [29] \\
\hline Trichoderma viride & UV-curable polymeric support & nd & Covalent & nd & nd & nd & {$[30]$} \\
\hline Trichoderma viride & Chitosan-xanthan hydrogels & nd & Covalent & 177 & 92 & nd & {$[31]$} \\
\hline Trichoderma viride & $\begin{array}{l}\text { Polyaniline treated with } \\
\text { glutaraldehyde }\end{array}$ & nd & Covalent & nd & nd & nd & {$[32]$} \\
\hline
\end{tabular}

nd: not determined

${ }^{a}$ Recovered activity refers to the activity observed in the derivative compared with the activity bound to the support. ${ }^{b}$ Immobilization yield refers to the percentage of activity bound to the support compared to the total activity offered to it. ${ }^{c}$ Stability factor refers to the ratio between the half-life values of the derivative and the soluble enzyme, at the specific temperatures described in parentheses.

with water. The immobilization on $\mathrm{CNBr}$-support was performed at $4^{\circ} \mathrm{C}$ for 15 minutes and then blocked with $1 \mathrm{M}$ ethanolamine at pH 8 for 2 hours. Finally derivative was washed with water. The purification-immobilization in one step was also performed using agarose heterofunctional supports activated with $\mathrm{Cu}^{2+}$-chelate groups and glyoxyl groups. For this, the first adsorption step was performed as was described above for monofunctional Copper activated supports and then the adsorbed enzyme was incubated at $\mathrm{pH} 10$ during 2 hours. Finally, the preparation was reduced with $1 \mathrm{mg} / \mathrm{mL}$ of solid $\mathrm{NaBH}_{4}$ for 30 minutes and then washed with water.

In order to control the processes of purification and immobilization, periodically, samples of the supernatant (enzyme solution without the support) and suspension (the whole mixture) were withdrawn, and the enzyme activity was measured.
The yield of immobilization (YI) and the expressed activity (EA) were determined as:

YI $(\%)=\frac{\text { Total activity offered to support }- \text { unbound enzyme activity }}{\text { Total activity offered to support }} \times 100$ Total activity offered to support

EA $(\%)=\frac{\text { Total activity observed on the derivatives }}{\text { Total activity offered to support }} \times 100$

The total activity offered to support is the total number of units (U) added to the support for immobilization, and the unbound enzyme activity refers to the number of units $(\mathrm{U})$ found in the supernatant at the end of the immobilization process. 


\section{Thermal stability studies}

Thermal inactivation was carried out at different temperatures, with $1 \mathrm{~g}$ of immobilized derivative suspended in a $10 \mathrm{~mL}$ solution of 0.1 $\mathrm{M}$ acetate buffer at $\mathrm{pH}$ 5. Periodically samples of the suspension were withdrawn and their activities were tested as was described above. The initial activity was considered as $100 \%$.

Inactivation was modeled based on the deactivation theory proposed by Henley and Sadana [40]. Inactivation parameters were determined from the best-fit model of the experimental data which was the one based on two-stage series inactivation mechanism with no residual activity. According to it, biocatalyst inactivation proceeds through two sequential steps of progressively less active enzyme species until a final completely inactive species is obtained, as represented in the following scheme:

$$
E \stackrel{k_{1}}{\longrightarrow} E_{1} \stackrel{k_{2}}{\longrightarrow} E_{2}
$$

where $\mathrm{k}_{1}$ and $\mathrm{k}_{2}$ are first-order transition rates constants, $\mathrm{E}, \mathrm{E}_{1}$ and $\mathrm{E}_{2}$ are the corresponding enzyme species. The mathematical model representing this mechanism is:

$$
a=\left(1+\alpha\left(\frac{k_{1}}{k_{2}-k_{1}}\right)\right) \exp ^{\left(-k_{1} \cdot t\right)}-\left(\alpha\left(\frac{k_{1}}{k_{2}-k_{1}}\right)\right) \exp ^{\left(-k_{2} \cdot t\right)}
$$

where a represents the residual activity at time $t$ and $\alpha$ is the ratio of specific activity of enzyme species $E_{1}$ with respect of that of the native enzyme species $\mathrm{E}$.

Considering only one step mechanism of enzyme inactivation $\left(k_{2}=0\right)$, and residual activity $(\alpha \neq 0)$, the model is first order inactivation with residual activity, represented by:

$$
\mathrm{a}=(1-\alpha) \exp ^{\left(-\mathrm{k}_{1} \cdot \mathrm{t}\right)}+\alpha
$$

Inactivation parameters were determined from the best-fit model of the experimental data. Half-life (time at which the residual enzyme activity is half of its initial value; $t_{1 / 2}$ ) was used to compare the stability of the different biocatalysts, being determined by interpolation from the respective models described by Eq. (1) or Eq. (2).

\section{Influence of temperature on the activity of immobilized xylanase}

The activity of glyoxyl-agarose preparation or the soluble enzyme was assayed at different temperatures by diluting $2 \mathrm{mg}$ of soluble or $1 \mathrm{~g}$ of the derivative in $10 \mathrm{~mL}$ of $100 \mathrm{mM}$ sodium acetate buffer at $\mathrm{pH} 5$. The activity was measured as previously described.

\section{SDS-PAGE}

Samples were submitted to denaturing electrophoresis, based on the method described by Laemmli [41], using $12 \%$ polyacrylamide gel. Molecular mass standard consisted on phosphorylase b $(97 \mathrm{kDa})$, bovine serum albumin $(66 \mathrm{kDa})$, ovalbumin $(45 \mathrm{kDa})$, carbonic anhydrase $(30 \mathrm{kDa})$, trypsin inhibitor $(20.1 \mathrm{kDa})$ and $\alpha$-lactalbumin $(14.4 \mathrm{kDa})$. Gels were stained with Coomassie brilliant blue or with silver nitrate, according to Heukeshoven and Dernick [42].

High-Performance anion exchange chromatography with pulsed amperometric detection (HPAEC-PAD) analysis

Xylose and xylo-oligosaccharides (XOS) were analyzed by HPAECPAD using an ICS2500 Dionex system consisting of GP50 gradient pump, and ED50 electrochemical detector with a gold working electrode and $\mathrm{Ag} / \mathrm{AgCl}$ reference electrode. Analyses were carried out at $25^{\circ} \mathrm{C}$ on a CarboPac PA-1 column $(250 \times 4 \mathrm{~mm})$ in combination with a CarboPac PA-1 $(50 \times 4 \mathrm{~mm})$ guard column. Separations were performed at a flow rate of $1 \mathrm{~mL} / \mathrm{min}$ as previously described [21]. Quantification of xylose and XOS was performed by external calibration using standard solutions (XOS1 to XOS6).

\section{Results and discussion}

\section{Preparation of xylanase catalyst}

Purification and immobilization: The strain from $A$. niger was grown with powdered corncobs as carbon source. The obtained culture was composed by different proteins (Figure 2, lane 2). High enzymatic activity was detected when xylose was used as substrate confirming the production of endo-xylanases; on the opposite, activity was not detected when avicel, carboxymethylcellulose and $p$-nitrophenyl$\beta$ - $D$-xylopyranoside were used as substrates suggesting that these activities were not significantly produced in the conditions of the strain growing. Due that several xylanases were produced, a purification step is necessary. When the catalytic properties were evaluated, the obtained values represented an average of the individual properties of each enzyme, making difficult to find stability in production during the process. Thus, purification of the target enzymes was performed using different supports activated with groups capable of physically adsorb proteins, as cationic or anionic, metal chelate and phenyl boronate groups (Table 2). The amount of xylanase adsorbed varied depending on the used support. The maximal adsorption (50\%) was produced when $\mathrm{Cu}^{2+}$-chelate support was used for the purification. The adsorbed fraction was desorbed with $20 \mathrm{mM}$ imidazole and analyzed by SDSPAGE, showing a single $34 \mathrm{kDa}$-protein with xylanolytic activity (Figure 2 , lane 4 ). This enzyme, here named xylanase I (xyl I), corresponds with the $50 \%$ of the total endo-xylanase activity. The purification factor was 4.14 (Table 3).

The use of enzymes in industrial processes makes necessary its immobilization to be used as heterogeneous catalysts. Considering that the enzyme was selectively adsorbed and purified by adsorption on metal-chelate supports, the first tried strategy consisted in using a

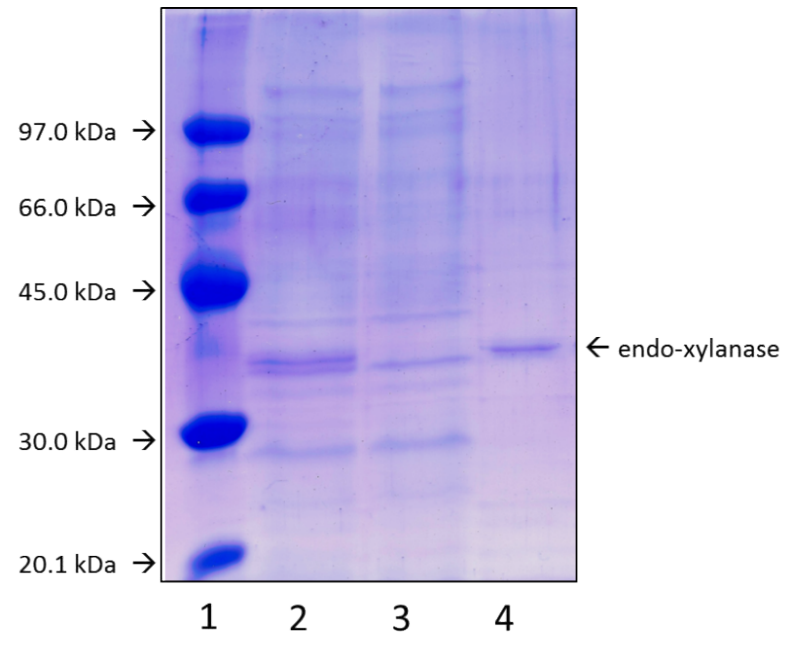

Figure 2. SDS-PAGE gel of the endo-1,4- $\beta$-xylanase purification. Lanes: (1) molecular weight markers; (2) crude protein extract from Aspergillus niger; (3) proteins non-adsorbed on $\mathrm{Cu}$-chelate agarose support; (4) endo-1,4- $\beta$-xylanase after desorption from $\mathrm{Cu}$-chelate agarose with $20 \mathrm{mM}$ imidazole. Experiment was performed as described in Methods 
Table 2. Adsorption of xylanase from A. niger on different supports

\begin{tabular}{|l|l|}
\hline Activated supports & Yield of immobilization (\%) \\
\hline Carboxymethyl-sepharose & 11 \\
\hline IDA-agarose & 17 \\
\hline Q-sepharose & 13 \\
\hline PEI-agarose & 8 \\
\hline Amino-agarose & 3 \\
\hline $\mathrm{Cu}^{2+}$-chelate agarose & 50 \\
\hline Boronate-agarose & 5 \\
\hline
\end{tabular}

Table 3. Protein and activity values after purification of the endo-1,4- $\beta$-xylanase from Aspergillus niger on $\mathrm{Cu}^{2+}$-chelate agarose

\begin{tabular}{|c|c|c|c|c|c|}
\hline & $\begin{array}{c}\text { Total protein } \\
\text { (mg) }\end{array}$ & $\begin{array}{c}\text { Total activity } \\
\text { (U) }\end{array}$ & $\begin{array}{c}\text { Specific activity } \\
\text { (U.mg }^{-1} \mathbf{)}\end{array}$ & $\begin{array}{c}\text { Yield } \\
\text { (\%) }\end{array}$ & $\begin{array}{c}\text { Purification } \\
\text { factor }\end{array}$ \\
\hline Crude extract & 26 & 52,8 & 2,03 & 100 & 1,00 \\
\hline Endo-xylanase I & 2,7 & 22,7 & 8,41 & 43 & 4,14 \\
\hline
\end{tabular}

heterofunctional metal-aldehyde activated support. This support is able to covalently immobilize the selectively adsorbed enzyme through an increase of the incubation $\mathrm{pH}$ that increase the nucleophilicity of the amine moieties of the enzyme improving the covalent immobilization to the aldehyde groups on the support surface [38]. The use of this support may permit the purification and covalent immobilization of the enzyme in only one step. The enzyme was immobilized at neutral $\mathrm{pH}$ and then the $\mathrm{pH}$ was increased to 10 to favor the covalent immobilization. Finally, a reduction process to convert the process into irreversible was performed. This process allowed the complete immobilization of xylanase I (50\% of the total xylanase activity) and no leakages were detected after measuring the amount of proteins by the Bradford's method, confirming that the enzyme was covalently immobilized. However, this protocol (incubation at alkaline $\mathrm{pH}$ plus reduction step) yielded inactive derivatives. Considering that a blank of soluble enzyme was active in alkaline conditions as well as in the presence of reductor, the inactivation has to come from the rigidification produced by the covalent multi-interaction with aldehyde groups of the support.

Thus, a protocol in two steps was tried. In a first step the enzyme was purified using $\mathrm{Cu}^{2+}$-activated supports as was described above and then the enzyme was immobilized. Considering that supports activated with different ionic exchangers or others as boronate activated supports were not able to immobilize this protein during the purification, the immobilization was tried using as aldehyde activated support. The immobilization on this support has to be performed at $\mathrm{pH} 10$. This permits the immobilization through the richest region in deprotonated amine groups that corresponds with the richest place in lysines [43]. The purified Xyl I was rapidly immobilized, in fact in 15 minutes more than $80 \%$ of this enzyme was bound to the support resulting completely immobilized after 2 hours (Figure 3). Finally the preparation was reduced to stabilize the linkages. The final expressed activity was around $80 \%$ compared with that of the soluble enzyme. The observed activity was $13 \mathrm{U} / \mathrm{g}$ of derivative.

The fraction of enzymes with xylanase activity not adsorbed to $\mathrm{Cu}^{2+}$-support was also offered to glyoxyl support. The immobilization resulted very slow, in fact, after $2 \mathrm{~h}$ it was not detectable and only after 48 hours $70 \%$ of this fraction was covalently attached to support. This result confirms that the xyl II is an enzyme with different characteristics. Xyl I and xyl II were the two main xylanases in the extract and were the candidates to be studied in later studies. Both proteins were also immobilized using a highly reactive support as $\mathrm{CNBr}$-activated Sepharose. This support is able to immobilize through few linkages having similar properties to that of the soluble enzyme [43]. Using short immobilization times (around 15 minutes) only about 30\% of each enzyme (xyl I and xyl II) were separately immobilized keeping unaltered the initial activity.

The thermal stability of the different preparations was evaluated. After incubation at $60^{\circ} \mathrm{C}$ the half-life of the soluble enzymes xyl I and xyl II was around 18 and 7 minutes respectively. The stabilization factor of the $\mathrm{CNBr}$ derivatives was 6 and 5.5 fold compared with the respective soluble enzymes. The activity of the preparations immobilized on glyoxyl-agarose supports remained almost unaltered (Figure 4A). The incubation at higher temperature $\left(75^{\circ} \mathrm{C}\right)$ promoted the inactivation of the glyoxyl derivatives with a half-life of 3.5 and 0.8 hours for xyl I and II respectively (Figure 4B). The thermal stabilities of the different preparations of both enzymes suggested again that they were different enzymes.

Optimization of the stability of xyl I-glyoxyl-agarose derivative: Xyl I-glyoxyl derivative immobilized for 2 hours at alkaline $\mathrm{pH}$ resulted the most stable derivative. However, the increase of the incubation time at alkaline $\mathrm{pH}$ of different enzymes with glyoxyl supports produce derivatives with a higher number of covalent linkages resulting in preparations with different stabilities [36]. Considering this, the just immobilized enzyme was incubated with the support during different times before reduction and then the thermal stability was evaluated. The stability of the different derivatives increased with the incubation time. The maximal stability was obtained after incubation for 20 hours (Figure 5A). Longer incubation time did not yield more stable derivatives (data not shown).

The optimal preparation was compared with the soluble xyl I at $60^{\circ}$ C (Figure 5B). While the half-life of the soluble enzyme was around 18 minutes, the optimal preparation had a half-life of around 13.8 days. This resulted in a preparation with a stabilization factor of around 1100 fold compared with the soluble enzyme.

Activity of the optimal catalyst in different temperatures: The activity of the optimal immobilized preparation compared with the soluble enzyme (xyl I) was measured at different temperatures. The maximal activity of the soluble enzyme was shown at $55^{\circ} \mathrm{C}$ and then a decay of the activity was produced until less than $20 \%$ at $82^{\circ} \mathrm{C}$. The maximal activity of the optimal derivative was obtained at $65^{\circ} \mathrm{C}$. The activity was around $50 \%$ when it was measured at $82^{\circ} \mathrm{C}$ (Figure 6). This fact was related with the higher thermal stability of the immobilized preparation compared with the soluble enzyme.

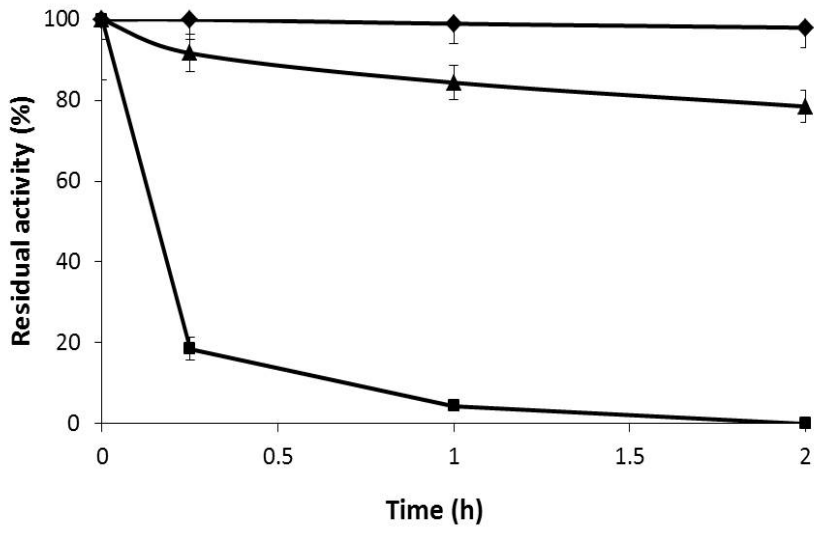

Figure 3. Immobilization of Xylanase I from A. niger on glyoxyl-agarose. Soluble enzyme $(\downarrow)$ supernatant ( $\mathbf{\square})$ and suspension $(\boldsymbol{\Delta})$. The reaction was performed in $100 \mathrm{mM}$ sodium bicarbonate buffer $\mathrm{pH} 10$ at $25^{\circ} \mathrm{C}$ 

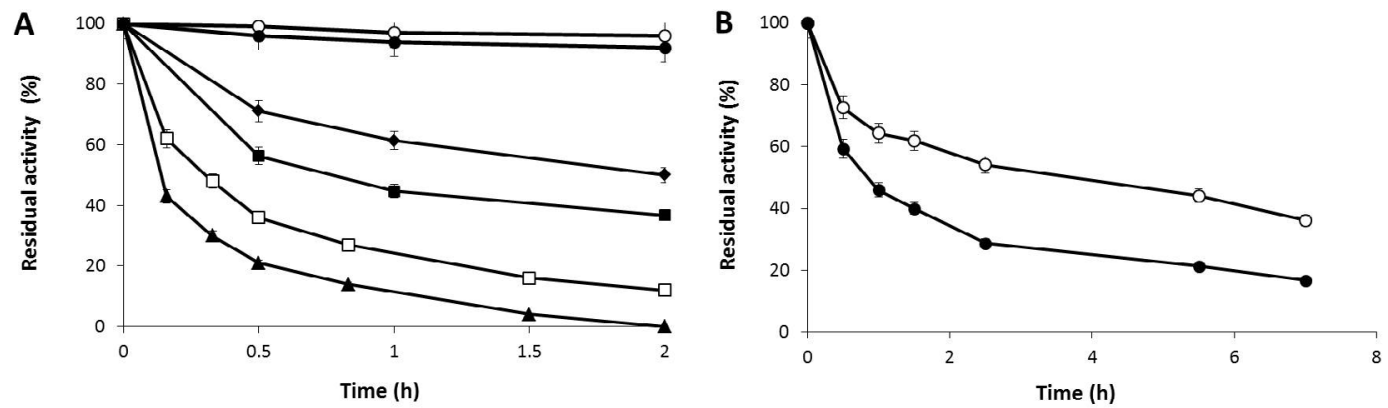

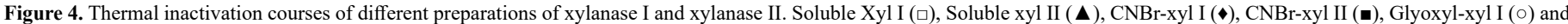
Glyoxyl-xyl II (•). Experiments were carried out at $60^{\circ} \mathrm{C}(\mathrm{A})$ and $75^{\circ} \mathrm{C}(\mathrm{B})$ and $\mathrm{pH} 5$
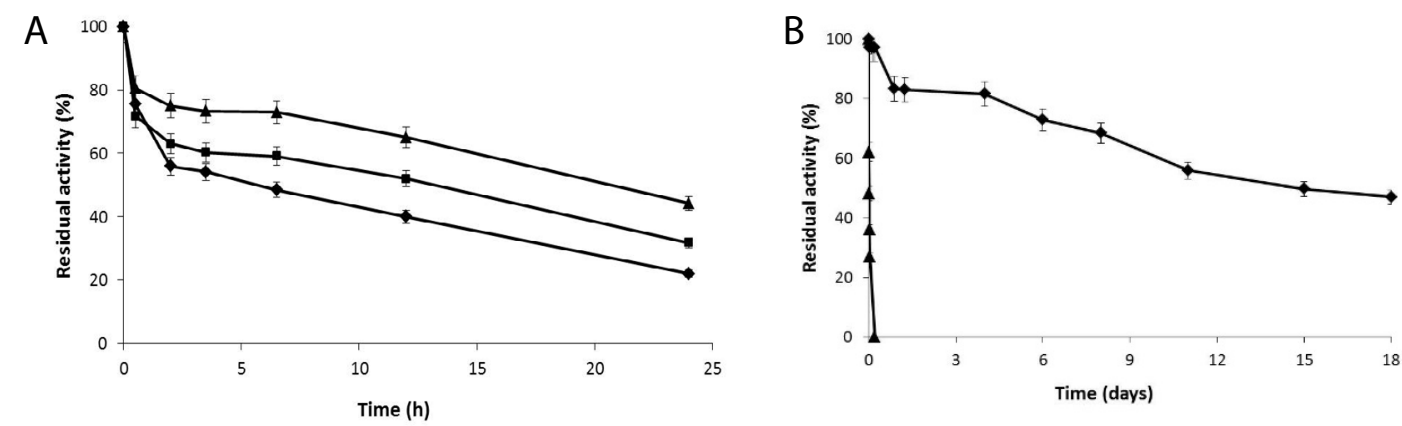

Figure 5. A) Thermal inactivation of Xyl I glyoxyl agarose preparations immobilized incubated for 2 hours and then incubated for different times at pH 10 . Derivatives obtained with no extra incubation ( $\downarrow)$ and after $5 \mathrm{~h}(\boldsymbol{-})$ and $20 \mathrm{~h}(\boldsymbol{\Lambda})$ of incubation. Experiments were carried out at $70^{\circ} \mathrm{C}$ and $\mathrm{pH}$ 5. B) Thermal inactivation of xyl I immobilized on glyoxyl-agarose and incubated at $\mathrm{pH} 10$ for $20 \mathrm{~h}(\bullet)$ and the soluble enzyme $(\mathbf{\Lambda})$. Experiments were carried out at pH 5 , at $60^{\circ} \mathrm{C}$

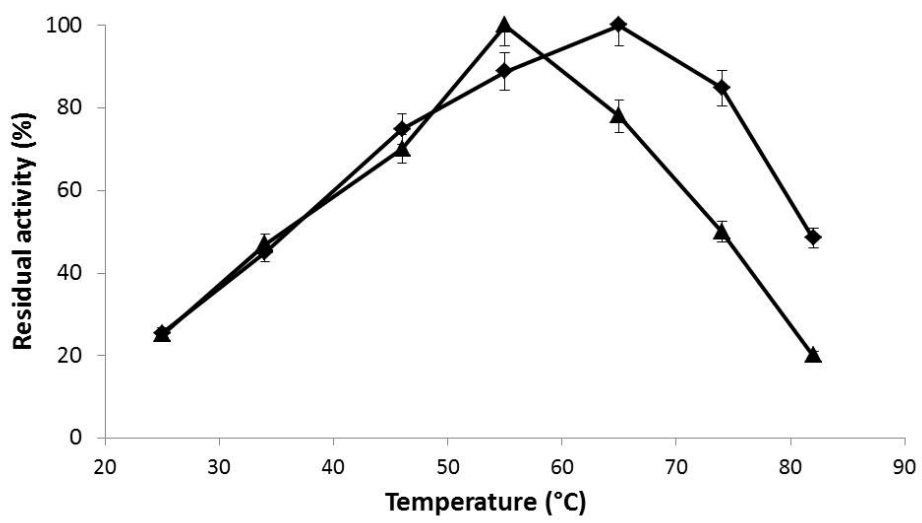

Figure 6. Influence of temperature on the enzymatic activity of xyl I soluble ( $\boldsymbol{\Delta})$ and immobilized on glyoxyl-agarose (४)

\section{Hydrolysis of xylan by the optimal glyoxyl derivative}

Hydrolysis of beechwood xylan catalyzed by the optimal preparation of endo-1,4- $\beta$-xylanase (xyl I) immobilized-stabilized on glyoxyl-agarose was performed at different temperatures $(4,25$ and $55^{\circ} \mathrm{C}$ ) and measured using the detection of reducing sugars (Figure 7). As expected the reaction rate strongly depended on the temperature. However the reaction rate is strongly decreased, the maximal conversion was the same independent of the conditions. This conversion value was the maximal using this preparation due that the derivative was performed with a pure endo-xylanase and it is not able to hydrolyze other esterifications with arabinose, glucuronic or acetylations in different positions. In order to compare the reaction curses at different temperatures this value was considered as $100 \%$ (maximal conversion measured by DNS method).
The different compounds produced at different times and temperatures were also studied (Table 4). Interestingly, the composition of the different reactions was different depending on the temperature which it was performed. Lower temperatures favored the appearance of compounds with 1-3 units of xylose. The formation of XOS with higher degree of polymerization (DP> 4 units of xylose) was favored by the increase of temperature. For instance, when the conversions were around $42-45 \%$ of the maximal obtained with this catalyst, the total amount of XOS 1-XOS 3 was 3.02, 1.64 and $1.18 \mathrm{mg} / \mathrm{mL}$ for 4,25 and $55{ }^{\circ} \mathrm{C}$, respectively and at $90 \%$ conversion, the amount of xylose was higher at 25 than at $55^{\circ} \mathrm{C}(1.17$ and $0.3 \mathrm{mg} / \mathrm{mL}$ respectively); contrarily, the production of XOS 4-XOS 6 was $0.78,0.91$ and $1.06 \mathrm{mg} / \mathrm{mL}$ when the reactions were performed at 4,25 and $55^{\circ} \mathrm{C}$ respectively. When $90 \%$ conversion was obtained, the amount of xylose was higher at 25 than 
Aragon CC (2018) Production of Xylo-oligosaccharides (XOS) by controlled hydrolysis of Xylan using immobilized Xylanase from Aspergillus niger with improved properties

at $55^{\circ} \mathrm{C}(1.17$ and $0.3 \mathrm{mg} / \mathrm{mL}$ respectively). Contrarily, the production of $\mathrm{X} 4-\mathrm{X} 6$ was $0.78,0.91$ and $1.06 \mathrm{mg} / \mathrm{mL}$ when the reactions were performed at 4,25 and $55^{\circ} \mathrm{C}$ respectively (Table 4 ).

Considering that the initial concentration of xylan solution was 20 $\mathrm{mg} / \mathrm{mL}$, the highest yield of production of xylose (X1) and XOS (XOS
2-XOS 6) was obtained when the reaction was performed at $55^{\circ} \mathrm{C}$ and at $100 \%$ of xylan conversion, achieving values of $73.4 \%(14.68 \mathrm{mg} / \mathrm{mL})$, $11 \%(2.20 \mathrm{mg} / \mathrm{mL})$ corresponding to xylose (Figure 8). However, when the conversion was $96.8 \%$, the production of xylose decreased to $5 \%$ $(0.98 \mathrm{mg} / \mathrm{mL})$, and $62 \%(11.93 \mathrm{mg} / \mathrm{mL})$ of prebiotic XOS (X2-X6) was obtained This is a very high conversion considering that in the extract

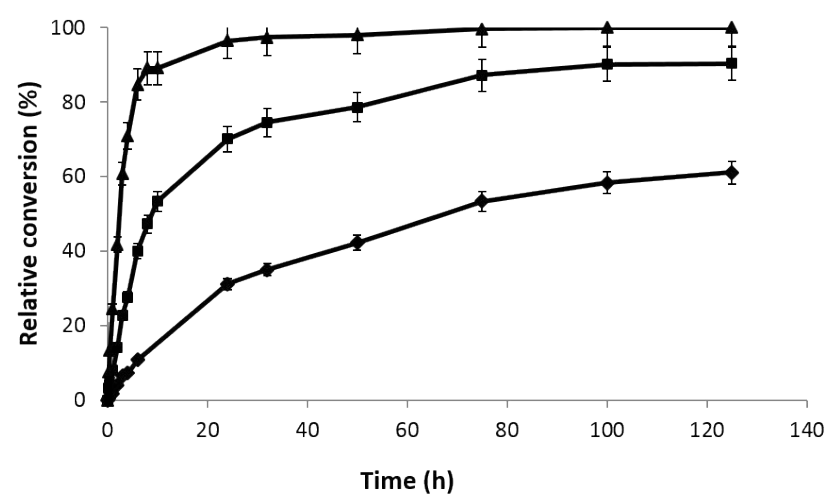

Figure 7. Hydrolysis course of beechwood xylan $(20 \mathrm{mg} / \mathrm{mL})$ by the xylanase I immobilized on glyoxyl-agarose at $4{ }^{\circ} \mathrm{C}(\bullet), 25^{\circ} \mathrm{C}(\boldsymbol{\bullet})$ and $55^{\circ} \mathrm{C}(\boldsymbol{\Delta})$ followed by measurement of reducing power (DNS method). Experiments were carried out at $\mathrm{pH} 5$

Table 4. Xylose and xylo-oligosaccharides (XOS) production after hydrolysis of beechwood xylan ( $20 \mathrm{mg} / \mathrm{mL})$ by the xylanase immobilized on glyoxyl-agarose, at different temperatures

\begin{tabular}{|c|c|c|c|c|c|c|c|c|c|}
\hline \multirow{2}{*}{$\begin{array}{c}\text { Temperature } \\
\left({ }^{\circ} \mathrm{C}\right)\end{array}$} & \multirow{2}{*}{$\begin{array}{c}\begin{array}{c}\text { Relative } \\
\text { Conversion }\end{array} \\
(\%)\end{array}$} & \multirow{2}{*}{$\begin{array}{c}\text { Time } \\
\text { (h) }\end{array}$} & \multicolumn{7}{|c|}{ Xylose and XOS (mg/mL) } \\
\hline & & & $\mathrm{X} 1$ & XOS2 & XOS3 & $\mathbf{X} 4$ & X5 & X6 & Total \\
\hline Control (xylan) & 4.5 & - & 0.00 & 0.00 & 0.00 & 0.09 & 0.03 & 0.04 & 0.16 \\
\hline \multirow{6}{*}{4} & 5.3 & 0.5 & 0.00 & 0.00 & 0.00 & 0.10 & 0.03 & 0.04 & 0.17 \\
\hline & 6.1 & 1 & 0.00 & 0.00 & 0.00 & 0.11 & 0.04 & 0.05 & 0.20 \\
\hline & 34.3 & 24 & 0.04 & 0.90 & 0.58 & 0.44 & 0.17 & 0.10 & 2.23 \\
\hline & 44.9 & 50 & 0.10 & 1.77 & 1.15 & 0.53 & 0.16 & 0.09 & 3.80 \\
\hline & 55.5 & 75 & 0.20 & 2.61 & 1.46 & 0.50 & 0.13 & 0.08 & 4.98 \\
\hline & 61.5 & 125 & 0.37 & 3.65 & 1.64 & 0.36 & 0.08 & 0.06 & 6.16 \\
\hline \multirow{5}{*}{25} & 8.6 & 0.5 & 0.00 & 0.00 & 0.00 & 0.12 & 0.05 & 0.05 & 0.22 \\
\hline & 12.1 & 1 & 0.00 & 0.05 & 0.04 & 0.16 & 0.07 & 0.06 & 0.38 \\
\hline & 42.7 & 24 & 0.01 & 0.89 & 0.74 & 0.53 & 0.24 & 0.14 & 2.55 \\
\hline & 75.7 & 32 & 0.43 & 4.65 & 1.88 & 0.32 & 0.06 & 0.06 & 7.40 \\
\hline & 90.9 & 125 & 1.17 & 6.69 & 1.26 & 0.15 & 0.04 & 0.05 & 9.36 \\
\hline \multirow{6}{*}{55} & 17.3 & 0.5 & 0.00 & 0.08 & 0.08 & 0.20 & 0.11 & 0.09 & 0.56 \\
\hline & 28.0 & 1 & 0.00 & 0.24 & 0.27 & 0.31 & 0.18 & 0.13 & 1.13 \\
\hline & 44.4 & 2 & 0.00 & 0.56 & 0.62 & 0.53 & 0.32 & 0.21 & 2.24 \\
\hline & 89.6 & 10 & 0.30 & 5.36 & 2.99 & 0.91 & 0.13 & 0.07 & 9.76 \\
\hline & 96.8 & 24 & 0.98 & 8.50 & 3.10 & 0.22 & 0.05 & 0.06 & 12.91 \\
\hline & 100.0 & 100 & 2.20 & 11.17 & 1.05 & 0.14 & 0.05 & 0.07 & 14.68 \\
\hline
\end{tabular}

X1) xylose, XOS: 2 xylobiose, 3 xylotriose, 4 xylotetrose, 5) xylopentose, 6) xylohexose. Experiments were performed as described in the Methods section.
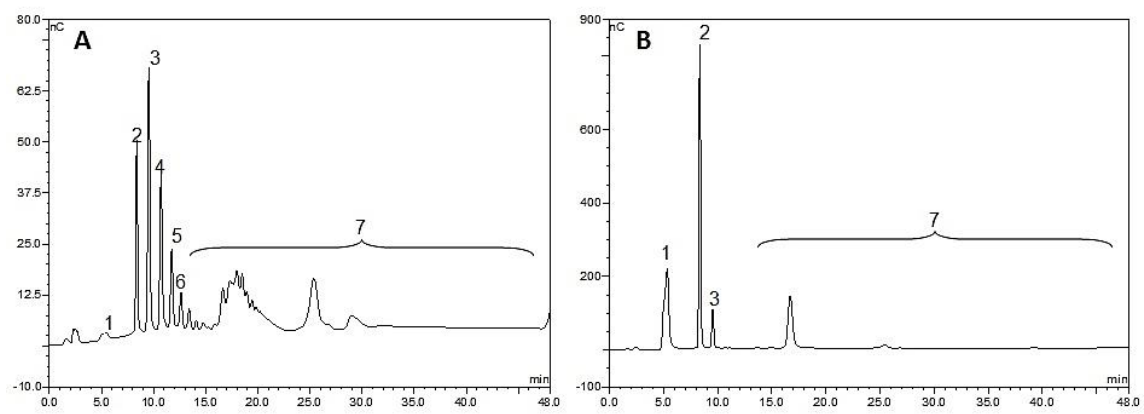

Figure 8. HPAEC-PAD chromatograms of products of hydrolysis of the soluble beechwood xylan $(20 \mathrm{mg} / \mathrm{mL})$ by the derivative xyl I-glyoxyl-agarose, after [A] $2 \mathrm{~h}$ ( $44 \%$ conversion) and [B] $100 \mathrm{~h}\left(100 \%\right.$ conversion) of hydrolysis, both at $\left.55^{\circ} \mathrm{C} .1\right)$ xylose, 2) xylobiose, 3) xylotriose, 4) xylotetrose, 5) xylopentose, 6) xylohexose, 7) other XOS of DP $>6$. Experiments were performed as described in the Methods section 

properties

apparently there are not another enzymes such as esterases and others and the rest of linkages with other sugars as arabinose or acetylations cannot be hydrolyzed.

\section{Conclusion}

The extracellular xylanase from A. niger produced with corncob as carbon source was easily purified, immobilized and stabilized in only two steps. The glyoxyl-derivative was around 1100 times more stable than soluble enzyme at $60^{\circ} \mathrm{C}$.

The optimal biocatalyst herein described presented qualities that allow the production of functional XOS with high added value from lignocellulosic materials. The high stability of the optimal catalyst allowed performing the hydrolysis at higher temperatures, increasing the rate of reaction and avoiding possible microbial contaminations. The final profile of XOS could be controlled by varying the temperature and time used in the process. The use of the developed process allowed producing $62 \%$ of oligo-saccharides of alimentary interest (X2-X6) from soluble xylan.

\section{Acknowledgements}

Ramón Areces foundation financial support is highly recognized. C.C. Aragon thanks Brazilian agencies FAPESP (2008/09332-8) and CAPES (3756-10-6) for financial support. This work was supported by the Spanish Government (AGL2017-84614-C2-1-R).

\section{References}

1. Collins T, Gerday C, Feller G (2005) Xylanases, xylanase families and extremophilic xylanases. FEMS Microbiol Rev 29: 3-23. [Crossref]

2. Azevedo AFC, de Oliva Neto P, Silva DF, Pastore GM (2013) Xylo-oligosaccharides from lignocellulosic materials: chemical structure, health benefits and production by chemical and enzymatic hydrolysis. Food Res Int 51: 75-85.

3. Polizeli ML, Rizzatti AC, Monti R, Terenzi HF, Jorge JA, et al. (2005) Xylanases from fungi: properties and industrial applications. Appl Microbiol Biotechnol 67: 577-591. [Crossref]

4. Lv Z, Yang J, Yuan H (2008) Production, purification and characterization of an alkaliphilic endo-3-14-xylanase. Enzyme Microb Technol 43: 343-348.

5. Biely P, Markovic O, Mislovicová D (1985) Sensitive detection of endo-1,4-betaglucanases and endo-1,4-beta-xylanases in gels. Anal Biochem 144: 147-151. [Crossref]

6. Dhiman SS, Kalyani D, Jagtap SS, Haw JR, Kang YC, et al. (2013) Characterization of a novel xylanase from Armillaria gemina and its immobilization onto $\mathrm{SiO} 2$ nanoparticles. Appl Microbiol Biotechnol 97: 1081-1091. [Crossref]

7. Sardar M, Roy I, Gupta MN (2000) Simultaneous purification and immobilization of Aspergillus niger xylanase on the reversibly soluble polymer Eudragit (TM) L-100. Enzyme Microb Technol 27: 672-679.

8. Chen H, Liu L, Lv S, Liu X, Wang M, et al. (2010) Immobilization of Aspergillus niger xylanase on chitosan using dialdehyde starch as a coupling agent. Appl Biochem Biotechnol 162: 24-32. [Crossref]

9. Pal A, Khanum F (2011) Covalent immobilization of xylanase on glutaraldehyde activated alginate beads using response surface methodology: characterization of immobilized enzyme. Process Biochem 46: 1315-1322.

10. Damásio ARDL, Silva TM, Almeida FBDR, Squina FM, Ribeiro DA, et al. (2011) Heterologous expression of an Aspergillus niveus xylanase GH11 in Aspergillus nidulans and its characterization and application. Process Biochem 46: 1236-1242.

11. Gawande PV, Kamat MY (1998) Preparation, characterization and application of Aspergillus sp. xylanase immobilized on Eudragit S-100. J Biotechnol 66: 165-175. [Crossref]

12. Gouda MK, Abdel-Naby MA (2002) Catalytic properties of the immobilized Aspergillus tamarii xylanase. Microbiol Res 157: 275-81.

13. Rogalski J, Szczodrak J, Dawidowicz A, Ilczuk Z, Leonowicz A (1985) Immobilization of cellulase and D-xylanase complexes from Aspergillus terreus F-413 on controlled porosity glasses. Enzyme Microb Technol 7: 395-400.
14. Aragon CC, Santos AF, Ruiz-Matute AI, Corzo, N, Guisan JM, et al. (2013) Continuous production of xylooligosaccharides in a packed bed reactor with immobilized-stabilized biocatalysts of xylanase from Aspergillus versicolor. J Mol Catal B Enzym 98: 8-14.

15. Lin YS, Tseng MJ, Lee WC (2011) Production of xylooligosaccharides using immobilized endo-xylanase of Bacillus halodurans. Process Biochem 46: 2117-2121.

16. Kapoor M, Kuhad RC (2007) Immobilization of xylanase from Bacillus pumilus strain MK001 and its application in production of xylo-oligosaccharides. Appl Biochem Biotechnol 142: 125-138. [Crossref]

17. Nagar S, Mittal A, Kumar D, Kumar L, Gupta VK (2012) Immobilization of xylanase on glutaraldehyde activated aluminum oxide pellets for increasing digestibility of poultry feed. Process Biochem 47: 1402-1410.

18. Manrich A, Komesu A, Adriano WS, Tardioli PW, Giordano RLC (2010) Immobilization and stabilization of xylanase by multipoint covalent attachment on agarose and on chitosan supports. Appl Biochem Biotechnol 161: 455-467.

19. Dhiman SS, Jagtap SS, Jeya M, Haw JR, Kang YC, et al. (2012) Immobilization of Pholiota adiposa xylanase onto $\mathrm{SiO}_{2}$ nanoparticles and its application for production of xylooligosaccharides. Biotechnol Lett 34: 1307-1313. [Crossref]

20. Sarbu A, de Pinho MN, Freixo MDR, Goncalves F, Udrea I (2006) New method for the covalent immobilization of a xylanase by radical grafting of acrylamide on cellulose acetate membranes. Enzyme Microb Technol 39: 125-130.

21. Aragon CC, Mateo C, Ruiz-Matute AI, Corzo N, Fernandez-Lorente G, et al. (2013) Production of xylo-oligosaccharides by immobilized-stabilized derivatives of endoxylanase from Streptomyces halstedii. Process Biochem 48: 478-483.

22. Ai Z, Jiang Z, Li L, Deng W, Kusakabe I, et al. (2005) Immobilization of Streptomyces olivaceoviridis E-86 xylanase on Eudragit S-100 for xylo-oligosaccharide production. Process Biochem 40: 2707-2714.

23. Maalej-Achouri I, Guerfali M, Gargouri A, Belghith H (2009) Production of xylooligosaccharides from agro-industrial residues using immobilized Talaromyces thermophilus xylanase. J Mol Catal B Enzym 59: 145-152.

24. Yan X, Wang X, Zhao P, Zhang Y, Xu P, et al. (2012) Xylanase immobilized nanoporous gold as a highly active and stable biocatalyst. Microporous Mesoporous Mater 161 $1-6$

25. Edward VA, Pillay VL, Swart P, Singh S (2002) Immobilization of xylanase from Thermomyces lanuginosus SSBP using Eudragit S-100. S Afr J Sci 98: 553-554.

26. Li L, Zhua Y, Huang Z, Jiang Z, Chena W (2007) Immobilization of the recombinant xylanase B (XynB) from the hyperthermophilic Thermotoga maritima on metal-chelate Eupergit C 250L. Enzyme Microb Technol 41: 278-285.

27. Simpson HD, Haufler UR, Daniel RM (1991) An extremely thermostable xylanase from the thermophilic eubacterium Thermotoga. Biochem $J$ 277: 413-417.

28. Cano Á, Minguillón C, Palet C (2006) Immobilization of endo-1,4- $\beta$-xylanase on polysulfone acrylate membranes. J Membr Sci 280: 383-388.

29. Xu Z, Miao Y, Chen JY, Jiang X, Lin L, et al. (2011) Co-immobilization mechanism of cellulase and xylanase on a reversibly soluble polymer. Appl Biochem Biotech 163: 153-161.

30. Akdemir ZS, Demir S, Kahraman MV, Apohan NK (2011) Preparation and characterization of UV-curable polymeric support for covalent immobilization of xylanase enzyme. J Mol Catal B Enzym 68: 104-108.

31. Dumitriu S, Chornet E (1997) Immobilization of xylanase in chitosan-xanthan hydrogels. Biotechnol Prog 13: 539-545.

32. Madakbas S, Demir S, Kahraman MV (2013) Xylanase immobilization on functionalized polyaniline support by covalent attachment. Starch-Stärke 65: 146-150.

33. Benedetti ACEP, Costa ED, Aragon CC, Santos AF, Goulart AJ, et al. (2013) Low-cost carbon sources for the production of a thermostable xylanase by Aspergillus niger. Rev Cienc Farm Basica Apl 34: 25-31.

34. Miller GL (1959) Use of dinitrosalicylic acid reagent for determination of reducing sugar. Anal Chem 31: 426-428.

35. Bradford MM (1976) A rapid and sensitive method for the quantitation of microgram quantities of protein utilizing the principle of protein-dye binding. Anal Biochem 72 248-254. [Crossref]

36. Guisán JM (1988) Aldehyde-agarose gels as activated supports for immobilizationstabilization of enzymes. Enzyme Microb Technol 10: 375-382.

37. Mateo C, Abian O, Fernández-Lafuente R, Guisan JM (2000) Reversible enzyme immobilization via a very strong and nondistorting ionic adsorption on supportpolyethylenimine composites. Biotechnol Bioeng 68: 98-105. 
Aragon CC (2018) Production of Xylo-oligosaccharides (XOS) by controlled hydrolysis of Xylan using immobilized Xylanase from Aspergillus niger with improved properties

38. Mateo C, Bolivar JM, Godoy C, Rocha-Martin J, Pessela BC, et al. (2010) Improvement of enzyme properties with a two-step immobilization process on novel heterofunctional supports. Biomacromolecules 11: 3112-3117. [Crossref]

39. Armisen P, Mateo C, Cortés E, Barredo JL, Salto F, et al. (1999) Selective adsorption of poly-His tagged glutaryl acylase on tailor-made metal chelate supports. $J$ Chromatogr A 848: 61-70

40. Henley JP, Sadana A (1986) Deactivation theory. Biotechnol Bioeng 28: 1277-1285. [Crossref]
41. Laemmli UK (1970) Cleavage of structural proteins during the assembly of the head of bacteriophage T4. Nature 227: 680-685. [Crossref]

42. Heukeshoven J, Dernick R (1985) Simplified method for silver staining of proteins in polyacrylamide gels and the mechanism of silver staining. Electrophoresis 6: 103-112.

43. Mateo C, Abian O, Bernedo M, Cuenca E, Fuentes M, et al. (2005) Some special features of glyoxyl supports to immobilize proteins. Enzyme Microb Technol 37: 456462

Copyright: $\mathbb{C} 2018$ Aragon CC. This is an open-access article distributed under the terms of the Creative Commons Attribution License, which permits unrestricted use, distribution, and reproduction in any medium, provided the original author and source are credited. 